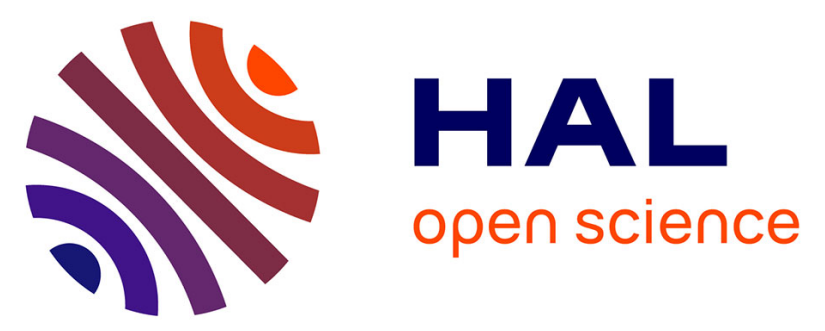

\title{
Release of arsenite, arsenate and methyl-arsenic species from streambed sediment impacted by acid mine drainage: a microcosm study.
}

Marina Hery, C. Casiot, E. Resongles, Zoe Gallice, O. Bruneel, Angélique Desoeuvre, S. Delpoux

\section{To cite this version:}

Marina Hery, C. Casiot, E. Resongles, Zoe Gallice, O. Bruneel, et al.. Release of arsenite, arsenate and methyl-arsenic species from streambed sediment impacted by acid mine drainage: a microcosm study.. Environmental Chemistry, 2014, 11 (5), pp.514-524. 10.1071/EN13225 . hal-02047987

\section{HAL Id: hal-02047987 \\ https://hal.science/hal-02047987}

Submitted on 8 Feb 2022

HAL is a multi-disciplinary open access archive for the deposit and dissemination of scientific research documents, whether they are published or not. The documents may come from teaching and research institutions in France or abroad, or from public or private research centers.
L'archive ouverte pluridisciplinaire HAL, est destinée au dépôt et à la diffusion de documents scientifiques de niveau recherche, publiés ou non, émanant des établissements d'enseignement et de recherche français ou étrangers, des laboratoires publics ou privés. 


\title{
Release of arsenite, arsenate and methyl-arsenic species from streambed sediment affected by acid mine drainage: a microcosm study
}

\author{
Marina Héry, ${ }^{\mathrm{A}, \mathrm{D}}$ Corinne Casiot, ${ }^{\mathrm{A}, \mathrm{C}, \mathrm{D}}$ Eléonore Resongles, ${ }^{\mathrm{A}}$ Zoe Gallice, ${ }^{\mathrm{A}}$ \\ Odile Bruneel, ${ }^{\mathrm{A}, \mathrm{B}}$ Angélique Desoeuvre ${ }^{\mathrm{A}}$ and Sophie Delpoux ${ }^{\mathrm{A}}$ \\ A Laboratoire HydroSciences Montpellier, HSM, UMR 5569 (IRD, CNRS, Universités Montpellier \\ 1 et 2), Université Montpellier 2, Place E. Bataillon, CC MSE, F-34095 Montpellier, France. \\ ${ }^{B}$ Laboratoire Mixte International Biotechnologie Microbienne et Végétale; Laboratoire de \\ Microbiologie et Biologie Moléculaire, Faculté des Sciences, Avenue Ibn Batouta BP1014, \\ Université Mohammed V. Rabat, Morocco. \\ ${ }^{\mathrm{C} C o r r e s p o n d i n g ~ a u t h o r: ~ c a s i o t @ m s e m . u n i v-m o n t p 2 . f r ~}$ \\ Doth authors contributed equally to this work.
}

Environmental context. Arsenic-rich waters generated from the oxidation of mining wastes are responsible for the severe contamination of river waters and sediments located downstream from mining sites. Under certain environmental conditions, the affected riverbed sediments may represent a reservoir for arsenic from which this toxic element may be released into water, mainly as a consequence of microbial activity.

\begin{abstract}
The (bio-)geochemical processes driving As mobilisation from streambed sediments affected by acid mine drainage (AMD) were investigated, and the structure of the bacterial community associated with the sediments was characterised. Microcosm experiments were set up to determine the effect of oxygen, temperature $\left(4\right.$ and $\left.20^{\circ} \mathrm{C}\right)$ and microbial activity on As mobilisation from contrasting sediments collected during high- (November 2011) and low(March 2012) flow conditions in the Amous River, that received AMD. Distinct bacterial communities thrived in the two sediments, dominated by Rhodobacter spp., Polaromonas spp. and Sphingomonads. These communities included only few bacteria known for their capacity to interact directly with As, whereas biogeochemical processes appeared to control As cycling. Major As mobilisation occurred in the As ${ }^{I I I}$ form at $20^{\circ} \mathrm{C}$ in anoxic conditions, from both November and March sediments, as the result of successive biotic reductive dissolution of $\mathrm{Mn}$ - and Fe-oxyhydroxides. The later process may be driven by Mn- and Fe-reducing bacteria such as Geobacter spp. and possibly occurred in combination with microbially mediated $\mathrm{As}^{\mathrm{V}}$ reduction. The involvement of other bacteria in these redox processes is not excluded. Biomethylation occurred only with the sediments collected at low-flow during oxic and anoxic conditions, although no bacteria characterised so far for its ability to methylate As was identified. Finally, sorption equilibrium of $\mathrm{As}^{\mathrm{V}}$ onto the sediment appeared to be the main process controlling $\mathrm{As}^{\mathrm{V}}$ concentration in oxic conditions. Comparison with field data shows that the later process, besides biomethylation, may be of relevance to the As fate in AMD-affected streams.
\end{abstract}

Additional keywords: bacterial communities, biomethylation.

\section{Introduction}

Acid mine drainage (AMD) represents a significant source of water pollution downstream from historic or current metal mining areas. ${ }^{[1]}$ These acid leachates resulting from sulfide oxidation contain high concentrations of iron and sulfate, together with toxic metals and metalloids. These elements precipitate upon AMD neutralisation in affected streams, resulting in ochreous (iron hydroxide rich) deposits covering the streambed. Thus, these sediments act as a chemical sink and contain high concentrations of metallic compounds. These toxic elements may be released into water as a result of seasonal and diurnal changes in the chemistry of the ochre ${ }^{[2,3]}$ or microbial activity. ${ }^{[4]}$ For this reason, affected sediments may represent a source for metals and metalloids, contributing to their transfer to the overlying streamwater and the ecosystem downstream. Streambed sediments are usually colonised by diverse microorganisms, which play key roles in ecosystem functioning and biogeochemical cycling. Their activity can affect metals and metalloids fate including the potential remobilisation of heavy metals from sediments into water. ${ }^{[5,6]}$ Among these contaminants, arsenic is of great concern because of its high toxicity for aquatic organisms and humans. Arsenic concentration may reach up to hundreds or thousands of milligrams per kilogram in the streambed sediment of rivers affected by AMD. ${ }^{[7-10]}$ Although the sediment is often considered to be an ultimate sink for As, an important issue is whether AMD-contaminated streambed sediment can serve as a source of As to the overlying stream water under certain conditions. 
In sediment of AMD-affected rivers, arsenic is generally associated to crystalline and amorphous Fe-, Al- and Mnoxyhydroxides, either as an adsorbed or co-precipitated species. The mobilisation of arsenic from these phases is mainly governed by sorption equilibria and abiotic or biotic (i.e. microbially mediated) redox reactions. Reductive dissolution of $\mathrm{Fe}$ - or Mn-oxyhydroxides, mainly due to $\mathrm{Fe}$ - or $\mathrm{Mn}$ reducing microorganisms activity, favours both $\mathrm{As}^{\mathrm{III}}$ and $\mathrm{As}^{\mathrm{V}}$ mobilisation, by solubilising As-bearing phases. ${ }^{[7,11-14]}$ The processes involved in As mobilisation have been extensively studied in groundwater but little attention has been paid to surface waters affected by AMD ${ }^{[4,15,16]}$ Furthermore, arsenic may exist in two oxidation states, whose sorption properties and dependence on $\mathrm{pH}$ differ widely. At neutral $\mathrm{pH}$, uncharged $\mathrm{As}^{\mathrm{III}}$ species $\left(\mathrm{H}_{3} \mathrm{AsO}_{3}\right)$ is usually less efficiently sorbed onto Fe-oxyhydroxides than anionic $\mathrm{As}^{\mathrm{V}}\left(\mathrm{H}_{2} \mathrm{AsO}_{4}^{-}\right)$, although this has been shown to not always be the case ${ }^{[17]}$; thus the reduction of $\mathrm{As}^{\mathrm{V}}$ to $\mathrm{As}{ }^{\mathrm{III}}$ will most likely enhance As mobilisation. This process may be mediated by microorganisms which thus trigger the release of arsenic into the aquatic environment. ${ }^{[14,18]}$ There are two microbial arsenate reduction systems: (i) a cytoplasmic arsenate reductase, part of the arsenic resistance pathway ${ }^{[19]}$ and (ii) a periplasmic dissimilatory arsenate reductase, part of a respiration system. ${ }^{[20]}$ Furthermore, previous studies did not explore arsenic biomethylation processes in AMD-affected rivers, although this process was shown to significantly contribute to As biogeochemical cycling in freshwater systems. ${ }^{[21,22]}$

In this study, we aimed to investigate the biogeochemical processes affecting As mobilisation from streambed sediments in the Amous River in Southern France, which is severely affected by $\mathrm{AMD}$ originating from a former $\mathrm{Pb}-\mathrm{Zn}$ mine. ${ }^{[23]}$ A previous study investigating arsenic contamination in Amous River showed that the dissolved arsenic concentration was generally higher than the environmental quality standard, with an average value of $30 \pm 23 \mu \mathrm{g} \mathrm{L}^{-1}$. ${ }^{[23]}$ Both oxidised and reduced As species were present and the $\mathrm{As}^{\mathrm{V}} / \mathrm{As}^{\mathrm{III}}$ ratio varied seasonally in relation to hydrological conditions and uncharacterised biogeochemical processes possibly involving waterstreambed sediment interactions. ${ }^{[9]}$ The approach used in the present study is based on microcosm experiments with streambed sediments collected at two contrasting seasons (high-flow in autumn and low-flow in spring), which were characterised for their element content (Fe, Mn, Al, Ca, As, Pb, Zn, S, K, Mg and organic $\mathrm{C}$ ) and the structure and composition of their bacterial communities. Mobilisation of inorganic $\left(\mathrm{As}^{\mathrm{III}}, \mathrm{As}^{\mathrm{V}}\right)$ and methylated (monomethyl- and dimethyl-) arsenic species into water was monitored during one month, under biotic or abiotic conditions, at either 4 or $20^{\circ} \mathrm{C}$ and under oxic or anoxic atmospheres. The main objectives were (i) to determine the influence of environmental parameters (oxygen, temperature) and microbial activity on As mobilisation from contaminated streambed sediments reflecting contrasting hydrological conditions and (ii) to compare the composition of the indigenous bacterial communities in these sediments showing different behaviour towards As mobilisation and evaluate the influence of environmental parameters on bacterial communities structure. Understanding how changes in redox conditions, temperature and microbial activity, alone or in combination, affect streambed sediment associated arsenic may assist in evaluating whether these sediments will become a residual source of As to the stream water (and to the downstream ecosystem) in the absence of AMD input.

\section{Site description}

The Amous River is located on the drainage basin of the Rhone River, in Southern France. This small stream receives the AMD (called the Reigous Creek) from the former $\mathrm{Pb}-\mathrm{Zn}$ Carnoulès mine, located on the south-eastern flank of the Massif Central. ${ }^{[24]}$ Exploitation closed in 1962 and left 1.5 MT of waste material remnant from the recovery process, still containing $0.7 \% \mathrm{~Pb}, 10 \% \mathrm{FeS}_{2}$ (pyrite) and $0.2 \% \mathrm{As}$, stored behind a dam on the uppermost course of Reigous Creek. Thus, the current source of Reigous Creek emerges at the base of the tailings dam; it is acidic $(2<\mathrm{pH}<3)$ and rich in dissolved $\mathrm{Fe}\left(0.5-1 \mathrm{~g} \mathrm{~L}^{-1}\right)$, As $\left(50-350 \mathrm{mg} \mathrm{L}^{-1}\right)$ and $\mathrm{SO}_{4}\left(2.0-7.7 \mathrm{~g} \mathrm{~L}^{-1}\right) .{ }^{[24]}$ Arsenic and iron are predominantly present as reduced $\mathrm{As}^{\mathrm{III}}$ and $\mathrm{Fe}^{\mathrm{II}}$ species in Reigous Creek. ${ }^{[25]}$ At $1500 \mathrm{~m}$ downstream from its source, the Reigous Creek joins the pristine and slightly alkaline $(\mathrm{pH}=$ $8.0 \pm 0.4)$ Amous River. After this junction, the fresh and clear water of the Amous River becomes, for some kilometres downstream, yellowish because of AMD neutralisation and subsequent precipitation of $\mathrm{Fe}$ in the form of ferrihydrite onto which arsenic and metals are partially trapped and settled to the streambed. The resulting $\mathrm{As} / \mathrm{Fe}$ ratio in riverbed sediment is $0.02-0.1$, with $10-30 \%$ As in the reduced form As ${ }^{\mathrm{III}} \cdot{ }^{[9]}$ Despite these attenuation processes, dissolved metal concentrations (Fe, Al, Mn, Co, Ni, Cu, Zn, Cd, Tl and Pb) in Amous River water are generally higher than the maximum concentrations allowed in European surface waters for priority substances (Ni, $\mathrm{Cd}$ and $\mathrm{Pb}$ ) and higher than the environmental quality standards for other elements. Dissolved As concentrations range from 5 to $134 \mu \mathrm{g} \mathrm{L}^{-1}$. ${ }^{23]}$ Seasonal variations of metal concentrations in Amous River water appear to be mainly controlled by hydrological conditions whereas arsenic concentration and speciation are also driven by biogeochemical processes, besides hydrological control. In particular, during base flow conditions in summer, the input of acid water to the Amous River is limited, thus making polluted streambed sediment a possible source of arsenic to the overlying water. ${ }^{[9,23]}$

\section{Experimental}

\section{Sample collection}

Two sampling campaigns reflecting contrasting hydrological regimes were carried out in November 2011 (high-flow conditions) and March 2012 (low-flow conditions). Sediment samples were collected in the Amous River 1200 m downstream from the confluence with the Reigous Creek (Amous DC station, global positioning system coordinates: $44^{\circ} 05^{\prime} 55^{\prime \prime} 10^{\prime \prime \prime} \mathrm{N}$, $3^{\circ} 59^{\prime} 38^{\prime \prime} 70^{\prime \prime \prime} \mathrm{E}$, located using a GPS 60 meter, Garmin, Nanterre, France). Orange loosely packed and watery sediments were collected at the top of the river bed using a sterile spoon and homogenised in an acid washed plastic box.

Water was collected from Amous DC and from a reference unpolluted site in the Amous River located 1500 m upstream from the confluence with the Reigous Creek (Amous UC station: $\left.44^{\circ} 06^{\prime} 33^{\prime \prime} 22^{\prime \prime \prime} \mathrm{N}, 3^{\circ} 59^{\prime} 13^{\prime \prime} 17^{\prime \prime \prime} \mathrm{E}\right)$. Samples were taken in acidcleaned polyethylene bottles. Subsamples for major ions, metal content ( $\mathrm{Al}, \mathrm{Mn}, \mathrm{Fe}, \mathrm{Zn}, \mathrm{Pb}$ ) and arsenic speciation determination were filtered in situ $(0.22 \mu \mathrm{m})$ and preserved using routine procedures. ${ }^{[23]} \mathrm{The} \mathrm{pH}$, temperature, conductivity, redox potential and dissolved oxygen (DO) concentration of water collected at UC and DC stations were measured in the field with an HQ40d Portable Multi-Parameter Meter (HACH Co., Loveland, CO, USA) equipped with a refillable $\mathrm{pH}$ electrode (pHC301), conductivity electrode (CDC401), gel filled ORP/Redox electrode 
(MTC101) and Luminescent DO probe (LDO101). Results are provided in Table S1 of the Supplementary material.

Water and sediment samples were transported to the laboratory in a cool box with ice-packs (1-h drive).

\section{Sample treatment}

Back in the laboratory, the sediments were sieved $(60 \mu \mathrm{m})$ and centrifuged for $5 \mathrm{~min}$ at $1000 \mathrm{~g}$ to remove the excess water. For element content determination, a subsample was dried at $105^{\circ} \mathrm{C}$ in an oven until constant weight. Approximately $100 \mathrm{mg}$ of the dried sediment sample was digested in closed Teflon reactors (Fisher Scientific, Illkirch, France) on hot-plates at $95^{\circ} \mathrm{C}$ for $24 \mathrm{~h}$ successively with (1) $\mathrm{H}_{2} \mathrm{O}_{2} 35 \%$, (2) a $4: 3: 0.13 \mathrm{~mL}$ concentrated $\mathrm{HNO}_{3}-\mathrm{HF}-\mathrm{HClO}_{4}$ mixture, (3) a $1: 3 \mathrm{~mL}$ concentrated $\mathrm{HNO}_{3}-\mathrm{HCl}$ mixture. Samples were cooled and evaporated to dryness between each step and at the end of the procedure. Samples were completed to $30 \mathrm{~mL}$ using $3 \mathrm{~mL} \mathrm{HNO}_{3}$ and double deionised water (Milli-Q). Finally samples were filtered to remove possible residues. For each set of samples, method blanks and international certified reference materials (Stream sediments LGC6189 from United Kingdom Accreditation Service and NCS DC70317 from LGC Standards) were also submitted to the digestion procedure.

The Amous river water from Amous UC was filtered sterilised $(0.22 \mu \mathrm{m})$. Subsamples for the analysis of major ions and arsenic speciation were kept at $4{ }^{\circ} \mathrm{C}$ and analysed within $24 \mathrm{~h}$ of collection. Subsamples for elemental analysis (Al, Zn, Pb, Fe, $\mathrm{Mn}, \mathrm{Ca}, \mathrm{Mg}, \mathrm{K}, \mathrm{As}$ ) were stored at $4{ }^{\circ} \mathrm{C}$ until analysis.

\section{Microcosm experiments set up}

Microcosms were set up within $6 \mathrm{~h}$ of sediment collection by mixing $3 \mathrm{~g}$ of the sieved and centrifuged sediment from Amous DC with $20 \mathrm{~mL}$ of filtered sterilised Amous water from Amous UC in acid-cleaned and autoclaved $50-\mathrm{mL}$ serum bottles. Each microcosm was maintained by sealing the serum bottle with a butyl rubber stopper and aluminium clamp. Biotic microcosms and abiotic (i.e. sterilised by autoclaving) microcosms were incubated under different conditions: (i) oxic, $4^{\circ} \mathrm{C}$; (ii) oxic, $20^{\circ} \mathrm{C}$; (iii) anoxic, $4{ }^{\circ} \mathrm{C}$ and (iv) anoxic, $20^{\circ} \mathrm{C}$. To assure oxygenation of the oxic microcosms during the incubation, a $0.22-\mu \mathrm{m}$ filter was placed on top of a needle inserted in the rubber stopper. Anoxic conditions were obtained by flushing the microcosms with sterile $\mathrm{N}_{2}$. Each biotic and abiotic microcosm was prepared in triplicate and all the chemical analyses detailed below were performed on all the triplicates. Slurry samples $(\sim 2 \mathrm{~mL})$ comprising a mix of sediment and water were removed from the bottles for analysis at days $0,2,6,13,23$ and 35. $\mathrm{pH}$ was immediately measured on $\sim 0.5 \mathrm{~mL}$ of the slurry and remained stable $(7.8 \pm 0.2)$ in all the microcosms within the first 13 days incubation (data not shown). The remaining slurry was centrifuged at $2400 \mathrm{~g}$ for $3 \mathrm{~min}$, and the supernatant (water) passed through a $0.22-\mu \mathrm{m}$ filter. A subsample of filtered water was acidified to $\mathrm{pH} 1$ with $\mathrm{HNO}_{3}$ Merck Suprapur (14.5 M) for determination of total dissolved $\mathrm{Al}, \mathrm{Fe}, \mathrm{Mn}$ and $\mathrm{As}$, and stored at $4{ }^{\circ} \mathrm{C}$ until analysis. Sediment pellets and filtered water samples for arsenic speciation were stored at $-80^{\circ} \mathrm{C}$ before further analyses.

\section{Chemical analyses}

The concentration of major anions and cations in Amous River water were analysed with a Dionex ICS-1000 Ion Chromatography System (Dionex France, Voisins-le-Bretonneux, France) using a conductivity method of detection. Element concentrations ( $\mathrm{Al}, \mathrm{Zn}, \mathrm{Pb}, \mathrm{Fe}, \mathrm{Mn}, \mathrm{Ca}, \mathrm{Mg}, \mathrm{K}, \mathrm{S}$ and $\mathrm{As}$ ) in Amous River, microcosm water and acid-digested sediment were determined using ICP-MS, X Series II (ThermoFisher Scientific, Courtaboeuf, France) equipped with a CCT (Collision Cell Technology) chamber. Quantitative analyses were performed using a conventional external calibration procedure with Indium as an internal standard to correct for instrumental drift and possible matrix effects. To ensure analytical precision of results, four certified reference materials (Stream sediments LGC6189 from United Kingdom Accreditation Service, NCS DC70317 from LGC Standards and SLRS-4 and PACS-2 from NRCC) were analysed; accuracy was better than $5 \%$ of certified concentrations, except for sulfur whose accuracy was comprised between 5 and $20 \%$ of certified concentration in PACS-2 (NRCC).

The organic carbon content in sediment was analysed at the SARM (Service d'Analyse des Roches et des Minéraux) Laboratory (Centre de Recherches Pétrographiques et Géochimiques (CRPG), Vandoeuvre-les-Nancy, France).

Arsenic speciation analysis in Amous River and microcosm water was performed by high performance liquid chromatography coupled with inductively coupled plasma mass spectrometry (HPLC-ICP-MS, SpectraSystem P4000, ThermoFisher Scientific) after thawing of the sample at ambient temperature. A strong anion-exchange Hamilton PRP-X100 column $(250 \times$ $4.6 \mathrm{~mm}$, Interchim, Montluçon, France) was used and either isocratic $\left(30 \mathrm{mM} \mathrm{NH} \mathrm{H}_{2} \mathrm{PO}_{4} /\left(\mathrm{NH}_{4}\right)_{2} \mathrm{HPO}_{4}\right.$ buffer, $\mathrm{pH}$ 8) or a two-step elution mode with eluent $\mathrm{A}\left(5 \mathrm{mM} \mathrm{NH}_{4} \mathrm{H}_{2} \mathrm{PO}_{4}\right)$ and eluent $\mathrm{B}\left(30 \mathrm{mM} \mathrm{NH} \mathrm{H}_{2} \mathrm{PO}_{4} /\left(\mathrm{NH}_{4}\right)_{2} \mathrm{HPO}_{4}\right.$ buffer, $\left.\mathrm{pH} 8\right)$; 0-4 min eluent $A$, then 4-10 min eluent $B$ and finally $10-20 \mathrm{~min}$

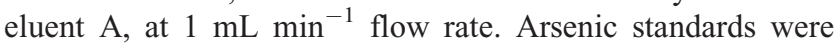
prepared from sodium arsenite $\left(\mathrm{NaAsO}_{2}\right.$, VWR, Fontenay sous Bois, France), sodium arsenate $\left(\mathrm{Na}_{2} \mathrm{HAsO}_{4}, 7 \mathrm{H}_{2} \mathrm{O}\right.$, SigmaAldrich, Saint-Quentin Fallavier, France), dimethylarsinic acid $\left(\left(\mathrm{CH}_{3}\right)_{2} \mathrm{As}(=\mathrm{O}) \mathrm{ONa}\right.$, Merck, Darmstadt, Germany $)$ and monomethylarsonic acid $\left(\mathrm{CH}_{3} \mathrm{AsO}_{3} \mathrm{Na}_{2}\right.$, Carlo Erba, Val-de-Reuil, France). For $50 \%$ of the samples analysed, the difference between the sum of arsenic species determined with HPLCICP-MS on frozen samples and the total As concentration determined with ICP-MS on acidified samples was less than $15 \%$. For $40 \%$ of the samples analysed, this difference ranges between 16 and $26 \%$. For samples collected after 13 days from biotic microcosms set up with March sediment incubated under anoxic conditions at $20^{\circ} \mathrm{C}$, this difference was $>26 \%$, reflecting a loss of As species, in relation with the extremely high Fe content (precipitation of As with $\mathrm{Fe}$ in non-acidified water subsamples). For this reason, speciation data recorded after 13 days will not be interpreted for the above mentioned experiment (i.e. March sediment, biotic, anoxic, $20^{\circ} \mathrm{C}$ ). No species conversion (in particular $\mathrm{As}^{\mathrm{III}}$ oxidation) occurred for samples from time $0\left(t_{0}\right)$ analysed prior and after freezing.

\section{Bacterial community analyses}

DNA was extracted from the sediment before microcosm incubation and from the sediment subsampled in the microcosms at the end of the biotic incubations using a UltraClean Soil DNA Isolation Kit (MOBIO Laboratories, Carlsbad, CA, USA), according to the manufacturer's instructions.

Nearly complete bacterial $16 \mathrm{~S}$ rRNA genes were amplified from the sediment before microcosm incubation using the universal primers $8 \mathrm{f}$ and 1489 r. $^{[26]}$ Polymerase chain reaction (PCR) products were purified using the GFX PCR DNA Purification Kit (GE Healthcare Life Sciences). The bacterial 
16S rRNA gene was then cloned into the pCR2.1-TOPO vector using the TOPO TA Cloning Kit (Invitrogen Inc., CA, USA) and One Shot TOP10 chemically competent Escherichia coli cells (Invitrogen). Sequencing was performed on 96 clones randomly picked in each library by GATC Biotech using primer M13F.

Sequences were submitted to a BLAST (basic local alignment search tool) $\operatorname{search}^{[27]}$ and checked for the presence of chimaeras using the UCHIME algorithm ${ }^{[28]}$ implemented in Mothur. ${ }^{[29]}$ Taxonomical classification was assigned to the clone sequences with Mothur, using the Wang method and three different databases and reference sequences (Silva, RDP, greengene). Results from the three classifications and results from BLAST were compared and the definitive classification comes about from a consensus (when different classifications were obtained with the different methods, the lowest taxonomic level common to all the methods was taken into account).

The bacterial ribosomal intergenic regions were amplified from the DNA extracted from the sediments before microcosm incubation as well as from the sediments subsampled at the end of the incubation in all the biotic microcosms using primers ITSF and ITSR according to Cardinale et al. ${ }^{[30]}$ Automated ribosomal intergenic spacer analysis (ARISA) was performed on an Agilent 2100 Bioanalyzer using the 7500 DNA kit (Agilent Technologies, Santa Clara, CA, USA).

\section{Results}

\section{Amous River streambed sediment characterisation \\ Element content}

Both streambed sediments were mainly composed of $\mathrm{Fe}$ $(10.8 \%), \mathrm{Ca}(>4 \%)$ and $\mathrm{Al}(3.6 \%)$ as major elements. High concentrations of $\mathrm{Zn}\left(26 \pm 4 \mathrm{~g} \mathrm{~kg}^{-1}\right)$ and $\mathrm{Pb}\left(2.6 \pm 0.8 \mathrm{~g} \mathrm{~kg}^{-1}\right)$ were also present. Organic carbon content was lower than $2 \%$. The sediment collected in November exhibited higher As (11.5 $\left.\mathrm{g} \mathrm{kg}^{-1}\right)$ and lower $\mathrm{Ca}(4.2 \%)$ content than the sediment collected in March $\left(5.6 \mathrm{~g} \mathrm{~kg}^{-1} \mathrm{As}, 12.3 \% \mathrm{Ca}\right)$, whereas other constituents ( $\mathrm{Mn}, \mathrm{K}, \mathrm{Mg}$ and $\mathrm{S}$ ) concentrations ranged between 1.7 and $4.9 \mathrm{~g} \mathrm{~kg}^{-1}$ (Table 1).

\section{Bacterial community analysis}

16S rRNA gene sequences analysis showed that the large majority (over $80 \%$ ) of the retrieved clones fell into the Proteobacteria phylum. Cyanobacteria represented 10 and $6 \%$ of the November and March libraries, whereas other phyla (Acidobacteria, Spirochaetes, Verrucomicrobia and Actinobacteria) were identified in minor proportions (data not shown). The March sediment library was clearly dominated by the Alphaproteobacteria class ( $71 \%$ of the clones) whereas Betaproteobacteria represented $48 \%$ of the clones in the November library. Gammaproteobacteria were identified in both libraires, whereas Deltaproteobacteria were detected only in sediment collected in November (Fig. 1a). The cyanobacteria that could be classified at the class level were related to the Oscillatoriophycidae whereas the sequences affiliated to the Actinobacteria and Acidobacteria could not be related with confidence to any class. At the family level, the November sediment clones were mainly affiliated to the Comamonadaceae, Sphingomonadaceae and Methylophilaceae, whereas the Rhodobacteraceae, Sphingomonadaceae and Legionellaceae dominated the March sediment library (Fig. 1b). Among the 14 and 11 genera identified in both 16S rRNA gene clone libraires, only three were common to the two sediments: Rhodobacter, Novosphingobium and Polaromonas. It is noteworthy that the majority of the
Table 1. Element concentrations $\left(\mathrm{g} \mathrm{kg}^{-1}\right)$ and organic carbon (OC) content (\%) in the two Amous riverbed sediments studied.

\begin{tabular}{lccccccccccc}
\hline Sampling date & $\mathrm{Fe}$ & $\mathrm{Ca}$ & $\mathrm{Al}$ & $\mathrm{Mn}$ & $\mathrm{K}$ & $\mathrm{Mg}$ & $\mathrm{S}$ & $\mathrm{Zn}$ & $\mathrm{As}$ & $\mathrm{Pb}$ & $\mathrm{OC}$ \\
\hline November 2011 & 107.9 & 42.0 & 36.3 & 1.9 & 4.9 & 1.7 & 1.9 & 22.9 & 11.5 & 3.2 & 1.5 \\
March 2012 & 107.8 & 123.3 & 36.0 & 4.1 & 2.5 & 3.2 & 3.6 & 28.3 & 5.6 & 2.0 & 1.8
\end{tabular}

November clones ( $66 \%$ ) could not be affiliated with confidence to any known genera. For example, among the Methylophilaceae related sequence, only one could be classified at the genus level (Methylophilus) (Fig. 1c).

\section{Microcosm experiments \\ Mobilisation of As under oxic conditions}

In all the microcosms incubated under oxic conditions (at 4 and $20^{\circ} \mathrm{C}$ ), an average of $14 \pm 5 \mu \mathrm{g} \mathrm{L}^{-1}$ of $\mathrm{As}^{\mathrm{V}}$ was measured in the water during the whole incubation period (Fig. 2). The concentration of $\mathrm{As}^{\mathrm{III}}$ in water was lower than $\sim 2 \mu \mathrm{g} \mathrm{L}^{-1}$, except in the experiment with March sediment incubated at $20^{\circ} \mathrm{C}$, for which a sharp increase of $\mathrm{As}^{\mathrm{III}}$ concentration was observed in water up to $\sim 90 \mu \mathrm{g} \mathrm{L}^{-1}$ after 6 days, followed by a decrease (Fig. 2d). Monomethyl- and dimethylarsenic species (MMA and DMA) were released from streambed sediment collected in March whereas these species were not released from the November sediment; the concentration increased from $3.2 \pm 0.2$ (MMA) and $0.6 \pm 0.1 \mu \mathrm{g} \mathrm{L}^{-1}$ (DMA) up to $5 \pm 1 \mu \mathrm{g} \mathrm{L}^{-1}$ (MMA) and $8 \pm 1 \mu \mathrm{g} \mathrm{L}^{-1}$ (DMA) at $4{ }^{\circ} \mathrm{C}$ or up to $12 \pm 1 \mu \mathrm{g} \mathrm{L}^{-1}$ (MMA) and $4.7 \pm 0.6 \mu \mathrm{g} \mathrm{L}^{-1}$ (DMA) at $20^{\circ} \mathrm{C}$ within the first 2 to 13 days of incubation and then decreased (Fig. 2e, f). In control sterilised experiments (i.e. abiotic microcosms), the concentration of $\mathrm{As}{ }^{\mathrm{V}}$, MMA and DMA species in water in contact with sediment remained stable throughout the incubation period whereas $\mathrm{As}^{\mathrm{III}}$ concentration continuously decreased (Fig. S1).

\section{Mobilisation of As under anoxic conditions}

Under anoxic conditions, there was a clear increase of $\mathrm{As}^{\mathrm{III}}$ concentration in water throughout the incubation period, up to $73-553 \mu \mathrm{g} \mathrm{L}^{-1}$ depending on sediment sample and temperature, whereas $\mathrm{As}^{\mathrm{V}}$ concentration remained lower than $60 \mu \mathrm{g} \mathrm{L}^{-1}$ (Fig. 3). The amount of $\mathrm{As}^{\mathrm{III}}$ mobilised into water was significantly higher at $20^{\circ} \mathrm{C}$ than at $4{ }^{\circ} \mathrm{C}$ with both November and March sediments. Methylated arsenic species were released into water from March sediment only, with a sharp increase of MMA and DMA concentration up to $12 \pm 0.7$ and $6.0 \pm 0.5 \mu \mathrm{g} \mathrm{L}^{-1}$ within the first 2 to 13 days of incubation. Both species were released more rapidly at $20^{\circ} \mathrm{C}$ than at $4{ }^{\circ} \mathrm{C}$ (Fig. 3e, f). Methylated species were not detected in microcosms set up with November sediment. In control sterilised experiments (i.e. abiotic microcosms), the concentration of dissolved $\mathrm{As}^{\mathrm{III}}$, $\mathrm{As}^{\mathrm{V}}$, MMA and DMA did not vary significantly throughout the incubation period (Fig. S2), similarly to what was observed for the abiotic oxic conditions. Arsenic mobilisation from November and March sediments in anoxic conditions was associated to Mn mobilisation at the early stage of incubation (for As $<200 \mu \mathrm{g} \mathrm{L}^{-1}$ ) and to Fe mobilisation at the later stages (for As $>200 \mu \mathrm{g} \mathrm{L}^{-1}$ ) (Fig. 4a, b).

\section{Shifts in bacterial community structures during microcosm incubations}

Whereas 16S rRNA gene analysis allowed the identification of the dominant bacterial groups present in the collected 
(a) Classes

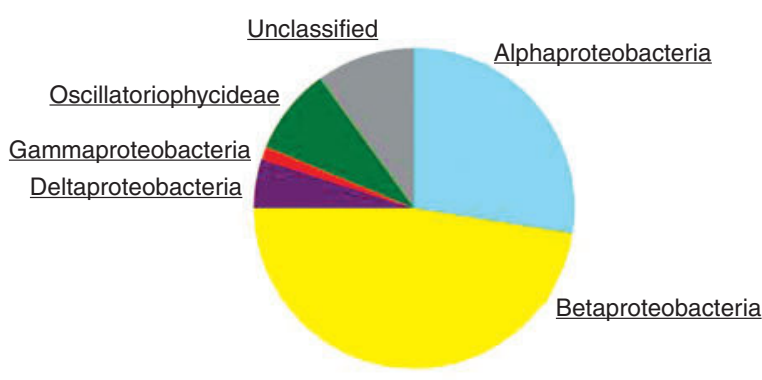

(b) Orders/ Families

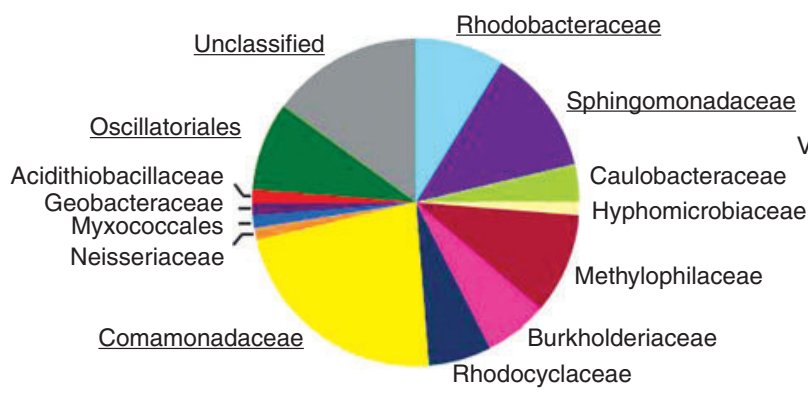

(c) Genera

November 2011

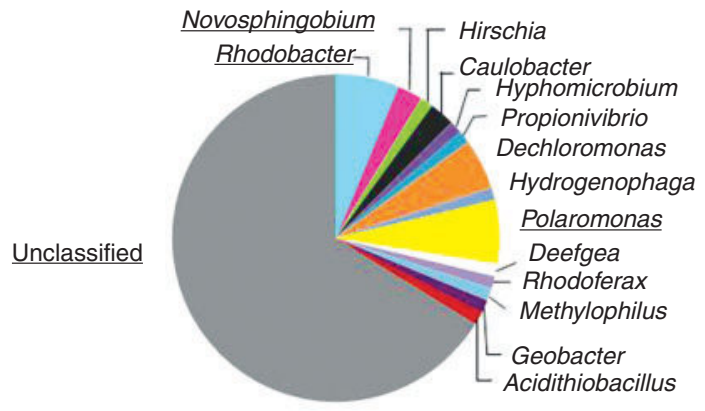

March 2012

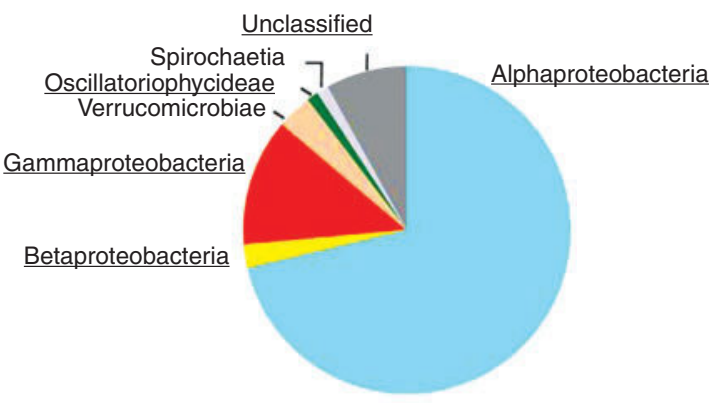

March 2012

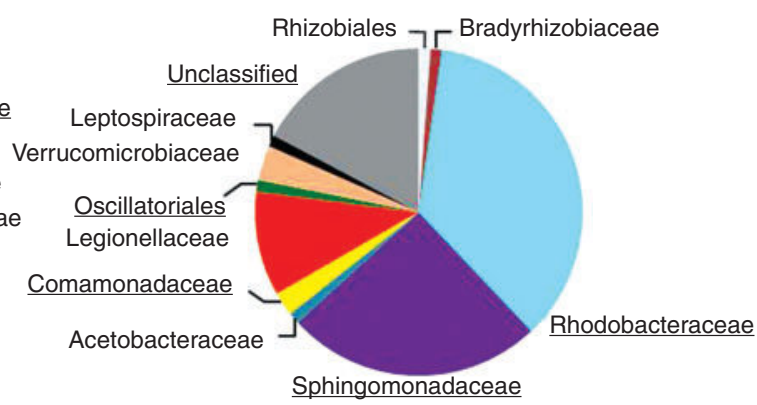

March 2012

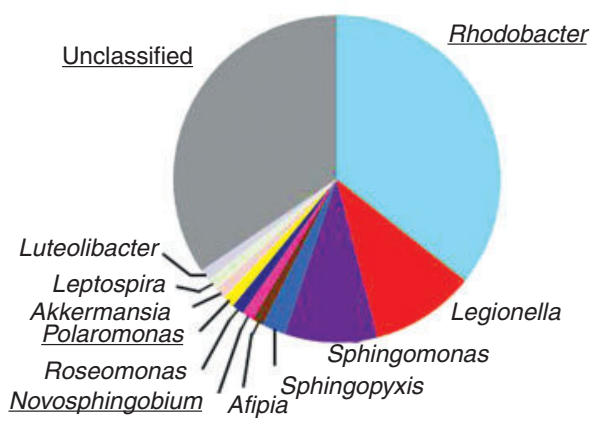

Fig. 1. Composition of bacterial community in Amous sediments collected in November and in March, as determined by 16S rRNA gene sequencing. Clone identification results are presented at the class level (a), the order and family level (b) and the genus level (c). Taxonomic groups common to the two libraries are underlined.

sediments, ARISA highlighted shifts occurring in the bacterial community structure during microcosm incubations under different oxygenation status and temperature. Sediments collected in high-flow (November) and in low-flow (March) conditions were initially characterised by different bacterial community structures as revealed by distinct ARISA profiles at day 0 , in agreement with $16 \mathrm{~S}$ rRNA gene sequencing results. Incubation conditions influenced the structure of the bacterial communities because all the profiles obtained at the end of the incubations differed from the initial ones, whatever the conditions of the incubation considered (Fig. 5). In March sediments incubated under oxic conditions at $20^{\circ} \mathrm{C}$, where $90 \mu \mathrm{g} \mathrm{L}^{-1}$ of $\mathrm{As}^{\mathrm{III}}$ and $12 \mu \mathrm{g} \mathrm{L}^{-1}$ of MMA were released, the ARISA profiles determined at the end of the incubation were dominated by an intense band that was not visible prior to incubation. In contrast, under oxic conditions at $4{ }^{\circ} \mathrm{C}$, where a lower amount of methylated species and no significant As release were observed, the profile of the community appears more complex, without any specific visible enrichment. Incubation under anoxic conditions (where $\mathrm{As}^{\mathrm{III}}$ is released from both sediments and MMA and DMA are released only from March sediment) at 4 or $20^{\circ} \mathrm{C}$ selected for complex and different bacterial communities in the two sediments (Fig. 5).

\section{Discussion}

Sediment composition and bacterial community structures

Amous River sediment contained high amounts of $\mathrm{Fe}$ and $\mathrm{Al}$, as generally encountered in AMD-affected streams (Nordstrom ${ }^{[31]}$ and references therein). Previous studies showed that 
ferrihydrite was the predominant mineral formed in Amous River downstream from the junction with Reigous Creek in contrasted hydrological conditions (i.e. spring and autumn) ${ }^{[9]}$ and that $\mathrm{Al}$ was incorporated in the structure of this mineral. ${ }^{[32]}$ Also, the abundance of calcium in November and March sediments is in agreement with the precipitation of calcium carbonate (calcite) previously evidenced in Amous river sediments. ${ }^{[9]}$ The higher amount of $\mathrm{Ca}$ in March sediments compared to November was consistent with the general increased precipitation of calcite during warmer months in mountain streams, in relation with primary productivity. ${ }^{[33]}$ The sediment also contained a few grams per kilogram of Mn that was usually shown to precipitate in the form of Mnoxyhydroxides in AMD-affected streams ${ }^{[34]}$; however, the mineralogy of Mn-bearing compounds in Amous river sediment has not been investigated yet. Finally, the sediments contained

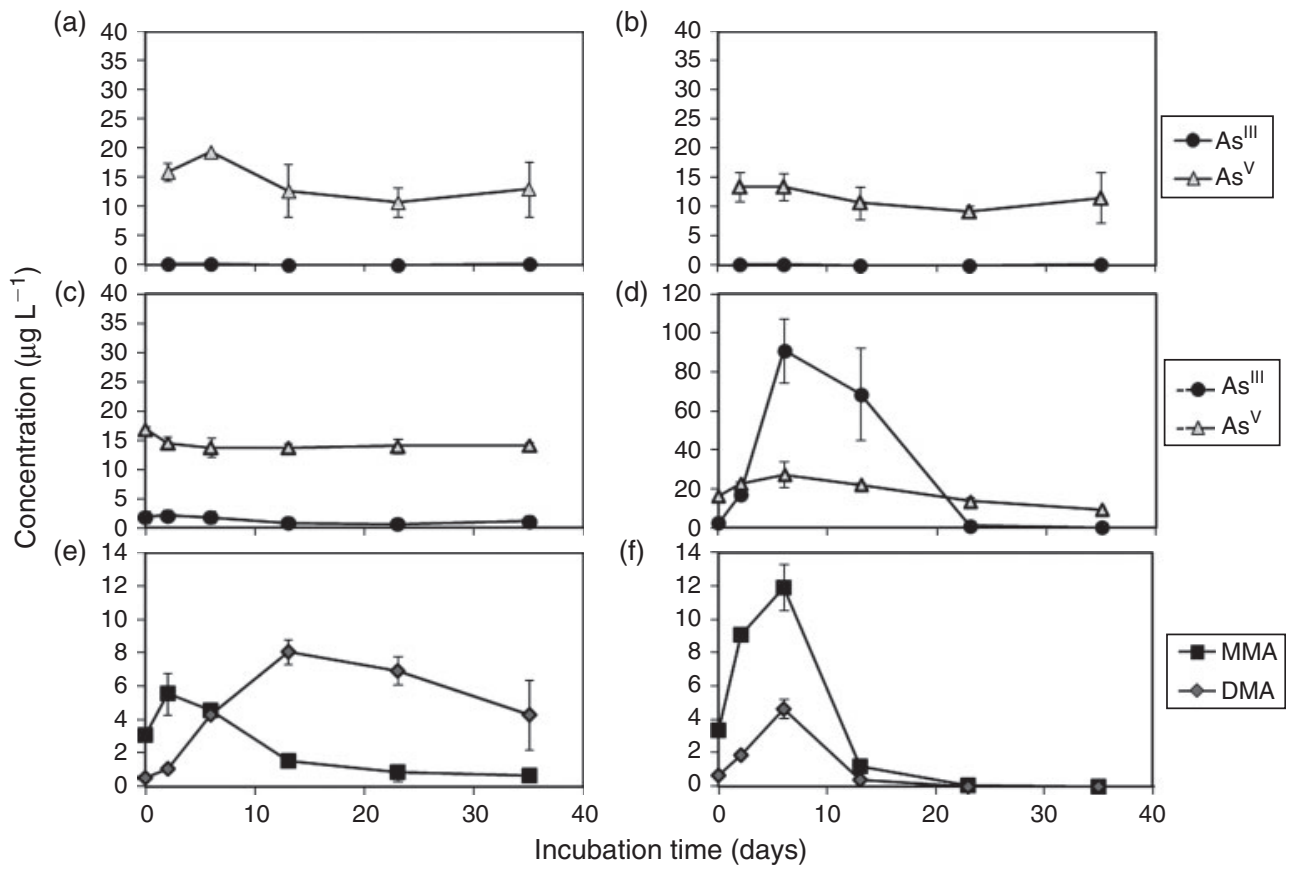

Fig. 2. Mobilisation of arsenic species in biotic microcosms set up with November (a, b) and March (c, $d, e, f)$ sediments incubated under oxic conditions at $4{ }^{\circ} \mathrm{C}(\mathrm{a}, \mathrm{c}, \mathrm{e})$ and $20^{\circ} \mathrm{C}(\mathrm{b}, \mathrm{d}, \mathrm{f})$. In microcosms set up with November sediments, mobilisation of monomethyl- (MMA) and dimethyl-arsenic (DMA) species was not observed.

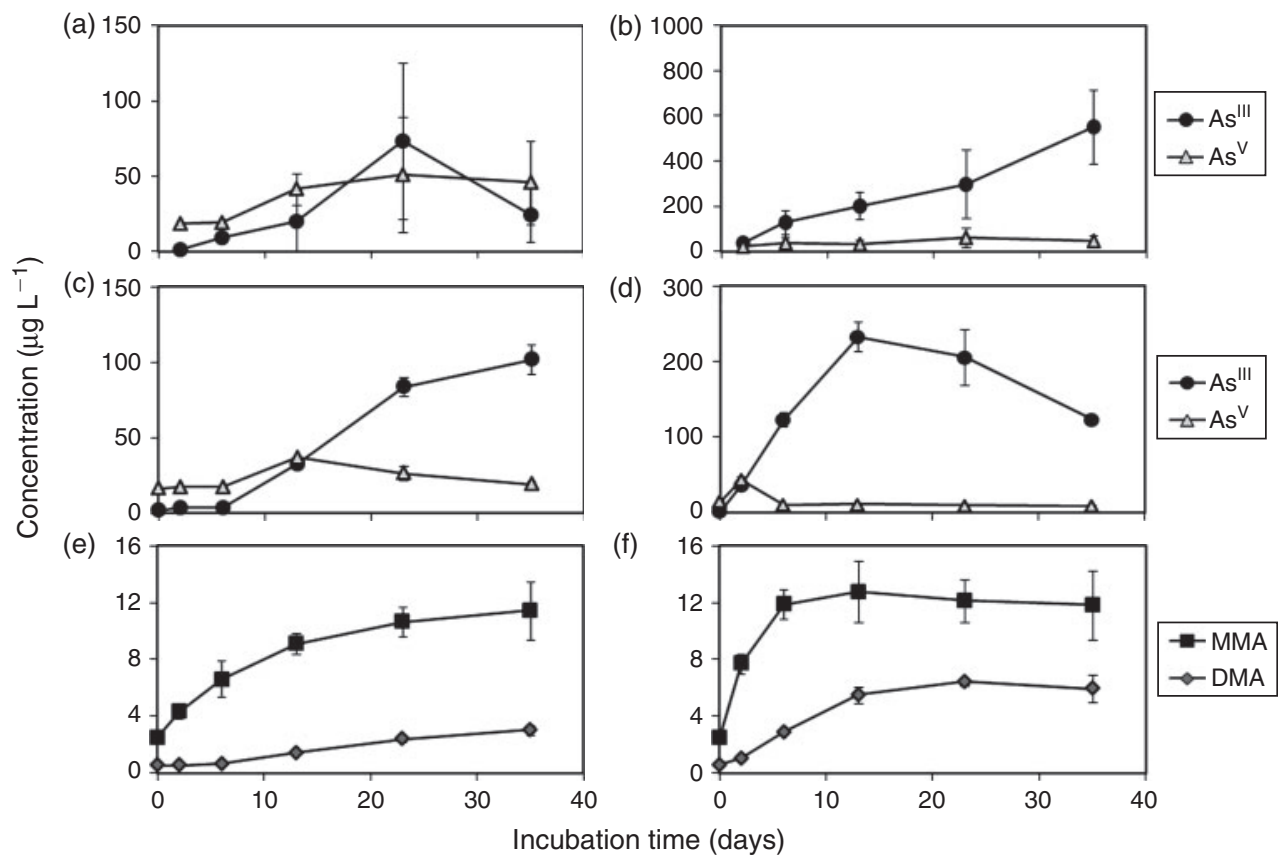

Fig. 3. Mobilisation of arsenic species in biotic microcosms set up with November (a, b) and March (c, d, e, f) sediments incubated under anoxic conditions at $4{ }^{\circ} \mathrm{C}(\mathrm{a}, \mathrm{c}, \mathrm{e})$ and $20^{\circ} \mathrm{C}(\mathrm{b}, \mathrm{d}, \mathrm{f})$. In microcosms set up with November sediments, mobilisation of monomethyl- (MMA) and dimethyl-arsenic (DMA) species was not observed. 


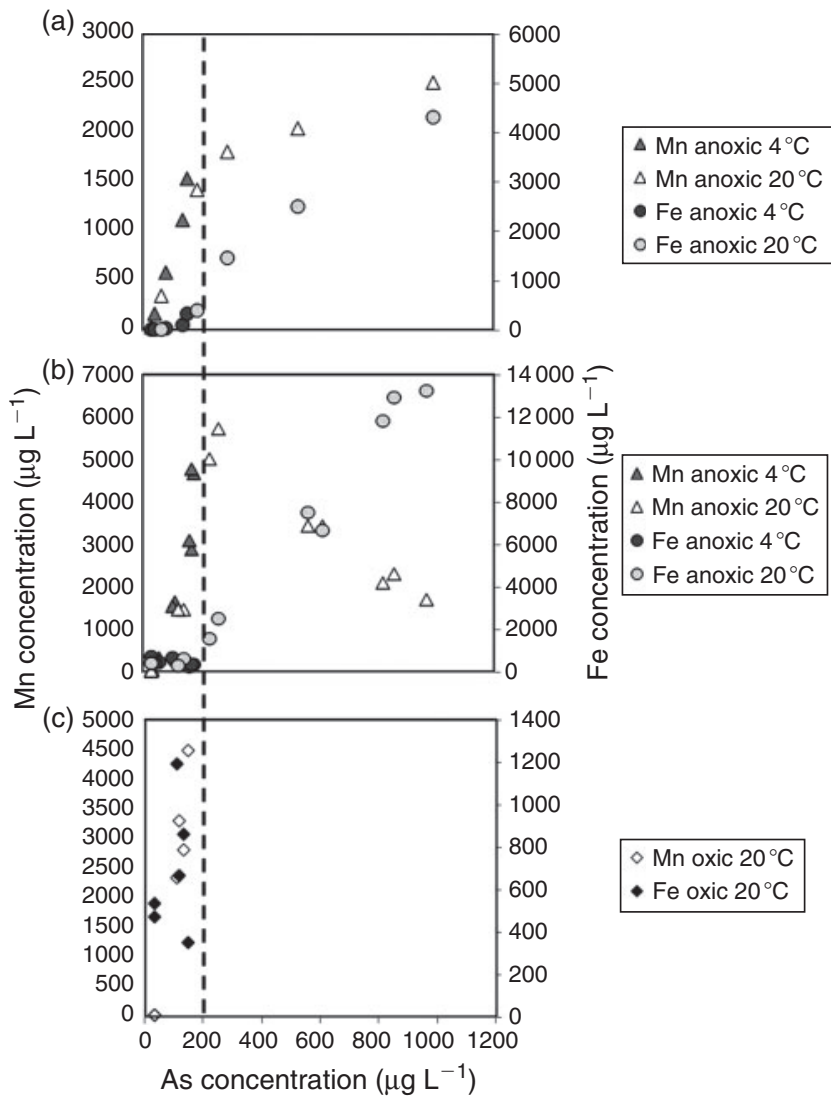

Fig. 4. Correlation between $\mathrm{Mn}, \mathrm{Fe}$ and As release into water in anoxic microcosms set up with November sediments (a), anoxic microcosms set up with March sediments (b) and oxic microcosms set up with March sediments (c). The vertical dotted line separates out the early stage of incubation $\left(\right.$ As $<200 \mu \mathrm{g} \mathrm{L}^{-1}$ ) from the latest stage of incubation (As $>200 \mu \mathrm{g} \mathrm{L}^{-1}$ ). sulfur; this element was shown to be associated to schwertmannite at a location closer to the Reigous-Amous confluence, and this sulfate-bearing mineral transformed into ferrihydrite at downstream stations along the Amous River flowpath. ${ }^{[9]}$ Sulfur might also subsist in the form of sulfides having emanated from the waste pile from which the AMD originates, ${ }^{[35]}$ although sulfide minerals were not detected in Amous sediments in previous studies. The As content of the November and March sediments is among the highest ever encountered for AMDaffected river sediments ${ }^{[36,37]}$ and within the range of that found previously. ${ }^{[9]}$ Twice more As was present in November sediment than in March sediment, reflecting higher As flux (aqueous and particulate phases) from the acid Reigous Creek in highflow conditions, in relation with increased AMD generation in the rainy season. ${ }^{[9,23]}$ Arsenic was previously found to be associated to Al-free and aluminous ferrihydrite in Amous River sediments, ${ }^{[9,32]}$ with a large predominance of $\mathrm{As}^{\mathrm{V}}(>69 \%$ of total $\mathrm{As}^{[9]}$ ) that formed inner-sphere surface complexes on these solid phases at $\mathrm{pH}>6 .^{[32]}$ Besides arsenic, Amous River sediment contained extremely high concentrations of $\mathrm{Pb}$ and $\mathrm{Zn}$, within the range of other AMD-affected streams. ${ }^{[38]}$

In spite of the high $\mathrm{As}, \mathrm{Pb}$ and $\mathrm{Zn}$ contents, the Amous streambed sediments are colonised by complex bacterial communities, characterised by distinct structures between high-flow (November) and low-flow (March) conditions. As determined by $16 \mathrm{~S}$ rRNA gene sequence analysis, photosynthetic bacteria Rhodobacter spp. dominated the two clone libraries. Commonly found in aquatic habitats, they can survive in metal rich environments and have light-dependent metal and metalloid oxidising or reducing capability, which make them interesting candidates for bioremediation. ${ }^{[39,40]}$ Polaromonas spp. and Dechloromas spp., also dominant in the November sediment clone library, have been described in pristine oligotrophic environments, as well as in coal-tar contaminated sediment ${ }^{[41]}$ and polluted river sediment. ${ }^{[42]}$ Bacteria referred to as
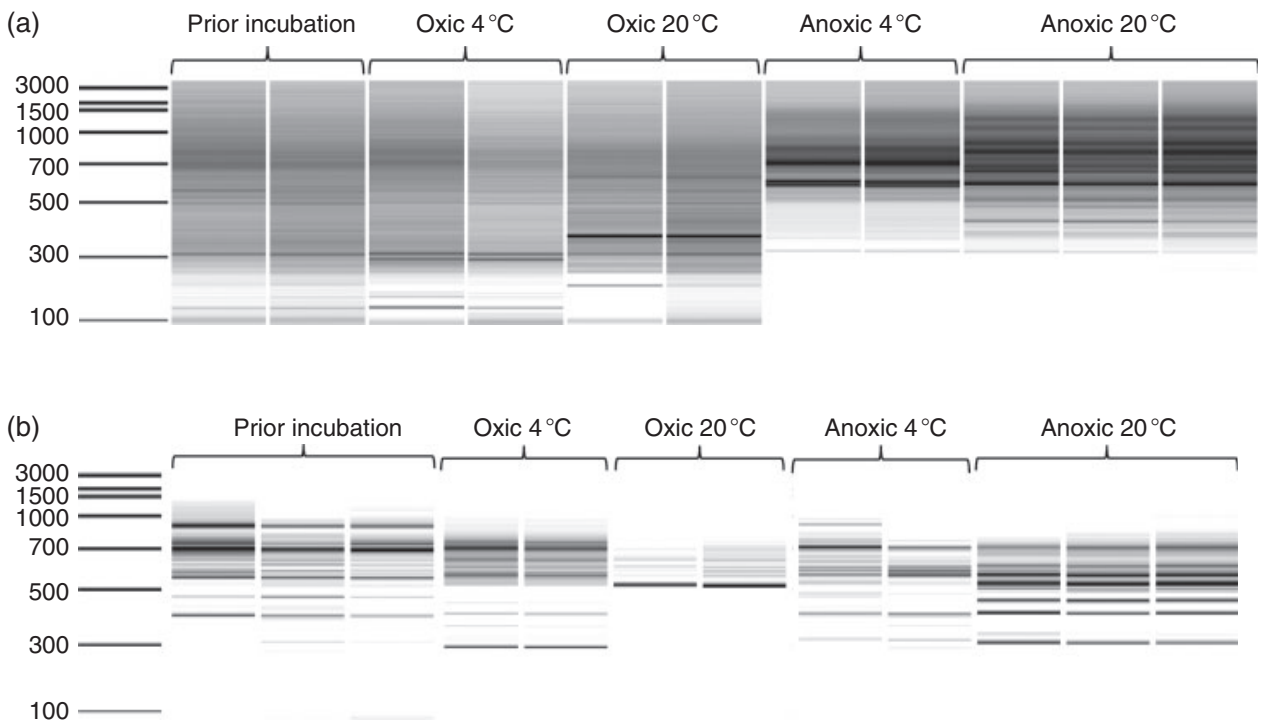

Fig. 5. ARISA profiles from streambed sediments collected in November (a) and in March (b): prior incubation and at the end of biotic incubation under oxic conditions at $4{ }^{\circ} \mathrm{C}$, oxic conditions at $20^{\circ} \mathrm{C}$, anoxic conditions at $4{ }^{\circ} \mathrm{C}$ and anoxic conditions at $20^{\circ} \mathrm{C}$. Results are shown for two or three microcosm replicates. The first lane corresponds to the molecular weight DNA ladder (size are indicated in base pairs). 
'sphingomonads' (i.e. belonging to genera Sphingomonas, Novosphingobium, or Sphingopyxis), detected in March sediments and to a lesser extent in November sediments, have the ability to use a wide range of organic compounds and to grow under low-nutrient conditions. They have been isolated from contaminated water, ${ }^{[43]}$ biofilms exposed to metallic contamination ${ }^{[44]}$ and stromatolites from alkaline hyperarsenic lake. ${ }^{[4]}$ The genus Novosphingobium was found to be an active member of aquifer sediment characterised by elevated aqueous arsenic concentration. ${ }^{[46]}$ Furthermore, their capacity to produce abundant exopolysaccharides and their lack of specific growth requirements ${ }^{[47]}$ could confer them an ecological advantage for their development inside biofilms in an oligotrophic environment such as the Amous streambed sediments. Only detected in the March sediment, Legionella spp. have already been detected in an AMD-affected environment. ${ }^{[48]}$ In spite of their relative abundance in the As rich Amous sediments, and the fact that most of them have been previously associated with metal or arsenic rich environments, there is no evidence of specific interaction between these dominant bacterial groups and the As cycle.

Only a few sequences from the high-flow (November) sediments were closely related to bacteria known for their capacity to affect - directly or indirectly - As behaviour in aquatic environments (i.e. Geobacter sp., Rhodoferax sp. and Acidithiobacillus sp.). This finding can be linked to the higher input of the Reigous acidic and As-rich waters to the Amous flow during the rainy season, which is also highlighted by highest As contents in the November sediment. The possible contribution of these bacteria to As release in the Amous river will be discussed further down this section.

\section{Mobilisation of $A s^{\prime \prime \prime}$ and $A s^{V}$}

Our data clearly demonstrated that substantial arsenic may be released from Amous River streambed sediment into water. The highest As release was obtained in anoxic microcosm experiments, where the predominant species mobilised was As ${ }^{\text {III }}$; this release was accompanied by a modification of the sediment bacterial community structure as revealed by the ARISA profiles. Arsenic mobilisation from November and March sediments in anoxic conditions appeared to be readily linked to reductive dissolution of Mn-oxyhydroxides that proceeded before reduction of Fe-oxyhydroxides (Fig. 4a, b); these successive steps were related to the higher redox potential of the $\mathrm{Mn}^{\mathrm{IV}}-\mathrm{Mn}^{\mathrm{II}}$ couple. The organic matter content higher than $1.5 \%$ in November and March sediments thus appeared to provide sufficient fuel for this reaction. The release of dissolved As associated with reductive dissolution of Fe- and Mn-oxyhydroxides was previously observed in various environments such as soils, lacustrine sediments and groundwater (Smedley and Kinniburgh ${ }^{[7]}$ and Nicholas et al. ${ }^{[49]}$ and references therein) but this process was rarely evidenced in AMD-affected streambed sediments. ${ }^{[4,50]}$ Although reductive dissolution of $\mathrm{Mn}$ - and Fe-oxyhydroxides may proceed abiotically, in the present study, no increase of soluble As was evidenced in abiotic (sterilised) microcosms (Fig. S2) while this process was favoured in biotic microcosms at $20^{\circ} \mathrm{C}$. This strongly suggested that temperature stimulated the activity of bacteria responsible for the release of As, Mn and Fe. Geobacter sp. detected in November sediment, are predominant $\mathrm{Fe}^{\mathrm{III}}$ - and $\mathrm{Mn}^{\mathrm{IV}}$-reducing microorganisms in a variety of sedimentary environments, and thus have the ability to drive the reductive dissolution of Mnand Fe-oxyhydroxides. Futhermore, the presence of Geobacter sp. has previously been correlated with $\mathrm{As}{ }^{\mathrm{III}}$ release in anoxic subsurface sediments ${ }^{[46,51-53]}$ and more recently, its influence in arsenic biogeochemistry in groundwater has been highlighted by a transcriptomic approach. ${ }^{[54]}$ The genus Rhodoferax, also identified in November sediment, includes at least an Fe $\mathrm{Fe}^{\text {III }}$ - and $\mathrm{Mn}^{\mathrm{IV}}$-reducing species ( $R$. ferrireducens). However, the fact that these species were not detected in March sediment suggests that either they are present but in low proportion or that other microorganism may be able to reduce $\mathrm{Mn}$ - and Feoxyhydroxides in Amous River streambed sediments, this function being largely widespread in the bacterial world.

In the present study, the greater mobilisation of $\mathrm{As}^{\mathrm{III}}$ during reductive dissolution contrasted with the usual predominance of $\mathrm{As}^{\mathrm{V}}$ in the Amous River sediment. ${ }^{[9,32]}$ This implies either preferential As ${ }^{\mathrm{III}}$ desorption or reduction of adsorbed $\mathrm{As}{ }^{\mathrm{V}}$. As ${ }^{\mathrm{III}}$ is desorbed more rapidly and extensively than $\mathrm{As}^{\mathrm{V}}$ from $\mathrm{Fe}-$ (hydr)oxides during reductive dissolution, in relation with a weaker binding of $\mathrm{As}^{\mathrm{III}} \cdot{ }^{[18]}$ In the same way, incongruent dissolution of Al-ferrihydrite upon reductive dissolution enhances the mobilisation of $\mathrm{As}^{\mathrm{III}}$ because of the low affinity of this species for $\mathrm{Al}$ sites that form at the Al-ferrihydrite surface. ${ }^{[55]}$ The latter process is suggested to proceed in the present microcosm study because of the lack of correlation between $\mathrm{Fe}$ and $\mathrm{Al}$ released in microcosms water (Fig. S3). Besides aforesaid abiotic processes that favour the release of $\mathrm{As}^{\mathrm{III}}$ initially trapped on the solid phase, the biotic reduction of $\mathrm{As}^{\mathrm{V}}$ into more soluble As ${ }^{\mathrm{III}}$ may also contribute to As mobilisation. ${ }^{[7]}$ Such a reduction could be the result of microbial detoxification (by the ars system, widespread among the bacteria) or of arsenate respiration. Whereas the detoxification reduction only concerns soluble $\mathrm{As}{ }^{\mathrm{V}}, \mathrm{As}^{\mathrm{V}}$ sorbed to the mineral phase can be reduced by arsenate respiration. G. uraniireducens has been shown to reduce $\mathrm{As}^{\mathrm{V}}$ sorbed to Fe-oxyhydroxides mobilising As ${ }^{\mathrm{III}},{ }^{[56]}$ strengthening the hypothesis that Geobacter sp., which was detected in November sediment, might play a role in $\mathrm{As}^{\mathrm{III}}$ mobilisation from streambed sediment affected by AMD. The distinction between a direct implication of these bacteria through sorbed $\mathrm{As}^{\mathrm{V}}$ dissimilatory reduction and an indirect implication through the reductive dissolution of $\mathrm{Fe}-$ Mn-oxyhydroxides would require further investigations.

Arsenic was mobilised to a lower extent in oxic conditions. The relatively stable $\mathrm{As}^{\mathrm{V}}$ concentration throughout the whole incubation period in both November and March oxic microcosms rather reflects sorption equilibria controlled concentration. A release of $\mathrm{As}^{\mathrm{III}}$ was definitely associated to $\mathrm{Mn}$ mobilisation in microcosms set up with March sediment incubated at $20^{\circ} \mathrm{C}$ (Figs $2 \mathrm{~d}, 4 \mathrm{c}$ ), thus implying the occurrence of a reductive dissolution process under seemingly aerated conditions. In this respect, Ying et al. ${ }^{[57]}$ showed that reductive dissolution of As, Mn and Fe actively occurs within the aggregate interiors of organic-rich soils regardless of oxygenation. However, we cannot exclude the biotic reduction of $\mathrm{As}^{\mathrm{V}}$, once released into the aqueous phase, by a resistance mechanism which may proceed both in anoxic and oxic conditions. Mobilisation of $\mathrm{As}^{\mathrm{III}}$ in oxic conditions was associated with the possible selection of a specific bacterial phylotype as reflected by the intense band emerging in the ARISA profile. Among the bacteria possibly involved in the As cycle in oxic conditions, one sequence related to sulphur-oxidising bacteria Acidithiobacillus spp. was retrieved from November sediment. Metal and metalloid release resulting from oxidation of sulfide minerals by $A$. ferrooxidans or $A$. thiooxidans is a well described process, generally referred to as 'bioleaching,. ${ }^{[58]}$ However, in the 
present study, there was no increase of As concentration in oxic conditions in the November microcosms during the course of the experiment and only sorption equilibrium appeared to control $\mathrm{As}^{\mathrm{V}}$ concentration. Whether Acidithiobacillus spp. or other bacteria are involved in the release of As from As-bearing sulfides in March microcosms remains uncertain. Another sequence identified in the November sediment was related to the genus Hydrogenophaga which include an As ${ }^{\mathrm{III}}$ oxidising strain ${ }^{[59]}$; the large predominance of $\mathrm{As}^{\mathrm{V}}$ over $\mathrm{As}{ }^{\mathrm{III}}$ in water from the November microcosm in oxic conditions actually matches with a potential $\mathrm{As}^{\mathrm{III}}$-oxidising activity in this sediment. However considering the lower solubility of $\mathrm{As}^{\mathrm{V}}$ compared to $\mathrm{As}^{\mathrm{III}}$, oxidation will contribute to As immobilisation rather than mobilisation.

\section{Biomethylation of arsenic}

Biomethylation activity was evidenced in the Amous sediments collected in March, during low-flow conditions. MMA and DMA have been partially formed in situ because they were already detected in the microcosm water at the very early stage of incubation (Figs 2,3) and also in abiotic (sterilised) experiments (Figs S1, S2). They were also produced during incubation experiments in biotic conditions, as suggested by increasing concentrations throughout incubation time, contrasting with unchanged concentrations in abiotic (sterilised) conditions. The oxygenation status of the overlying microcosm water did not appear to significantly influence the production of MMA and DMA whereas temperature stimulated their release into water. Methylated species were not detected in the microcosms set up with November sediments, suggesting conditions were not favourable to methylation or that microorganisms able to methylate As were not present or were inactive.

Methylation of arsenic is a widespread phenomenon mediated by aerobic and anaerobic bacteria (including cyanobacteria and $\mathrm{Fe}$ - and Mn-reducing bacteria), Archaea or Eukaryotes. ${ }^{[22,60-62]}$ This biological process has been described in soil, seawater and freshwater and is considered to significantly contribute to the global As biogeochemical cycling. ${ }^{[22,63]}$ To our knowledge, this is the first report of As biomethylation occurring in streambed river sediments affected by AMD.

No bacteria characterised so far for its capacity to methylate arsenic was identified in the clone libraries. However, among the bacteria possessing a putative ars $M$ gene (encoding an arsenite S-adenosylmethyltransferase) on their genome, the genus Geobacter was detected in the November sediment. Whether Geobacter spp., other $\mathrm{Fe}^{\mathrm{III}}$ - and $\mathrm{Mn}^{\mathrm{IV}}$-reducing bacteria, or other microorganisms are actually producing methylated forms of As in the Amous River requires further investigation. In particular, targeting the ars $M$ gene would provide information about the identity of the microorganisms carrying the ability to methylate As. ${ }^{[64]}$

\section{Environmental significance}

The Amous sediments can act as a reservoir from which toxic elements such as arsenic can be released through microbially driven mechanisms, in the absence of AMD input. Although anoxic conditions appear to be required for the mobilisation of the larger amounts of arsenic detected in this study (up to $\sim 500 \mu \mathrm{g} \mathrm{L}^{-1}$ of $\mathrm{As}^{\mathrm{III}}$ ), significant release can also occur (up to $\sim 100 \mu \mathrm{g} \mathrm{L}^{-1}$ ) under oxic conditions that prevail in flowing water in contact with the sediment in the field. Such phenomenon could prevent rivers located downstream of a former mining site to reach the 'good ecological status' of water targeted by the European Water Directive for 2015. The stimulation of As release by temperature is congruent with a three-year field study that showed the occurrence of peaks of dissolved As concentration during the warmer period in Amous River water. ${ }^{[23]}$ However, As speciation in the water of oxic microcosms set up with March sediment contrasted with field data. First, greater release of $\mathrm{As}^{\mathrm{III}}$ than $\mathrm{As}{ }^{\mathrm{V}}$ throughout incubation time in the March microcosm at $20^{\circ} \mathrm{C}$ contrasted with the general predominance of $\mathrm{As}^{\mathrm{V}}$ in Amous River water during the warmer period $^{[23]}$ and also during the March 2012 field survey (1.4 $\mu \mathrm{g} \mathrm{L}^{-1} \mathrm{As}^{\mathrm{III}}, 9.6 \mu \mathrm{g} \mathrm{L}^{-1} \mathrm{As}^{\mathrm{V}}$, see Table S1). Second, methylated As species have never been detected in the flowing water in the field. This implies that the processes taking place within the timescale of days in close contact with the sediment as evidenced in microcosms may have a limited influence on the composition of the flowing water in the field. Indeed, field parameters such as sediment-water contact time influenced by the river flow rate, may have a stronger effect on the extent to which arsenic species are leached from the sediment into the flowing water, as seen elsewhere. ${ }^{[50]}$ In particular, As ${ }^{\text {III }}$ mobilised into the aqueous phase upon reduction processes within sediment aggregates may be oxidised and readsorbed once the species migrated upward to the sediment-water interface, as observed in the hyporheic zone of contaminated rivers, ${ }^{[65]}$ thus explaining the predominance of $\mathrm{As}^{\mathrm{V}}$ in the flowing water. Sediment-water contact time may not be long enough to allow the release of a detectable concentration of methyl-As species in the flowing water. Moreover, we cannot exclude the volatilisation of the methylated form of arsenic as it was previously observed in Asiatic soils. ${ }^{[63]}$ Nevertheless, these results raise the question as to whether the methylation of As and its potential volatilisation have been overlooked with regard to their relevance to the mobilisation of As from polluted sediments. ${ }^{[66]}$

\section{Conclusions}

This study improves our understanding of the potential mechanisms involved in As behaviour at the sediment-water interface in a river affected by AMD:

(i) Polluted Amous streambed sediments can act as reservoir for toxic elements such as As, and As mobilisation from these sediment is principally microbially driven.

(ii) As mobilisation is likely to be promoted during summer (when higher temperatures stimulate microbial activity) and in anoxic (micro-) environments.

(iii) Complex microbial communities thrive in the Amous sediments with a wide range of metabolic capacities and the ability to interact directly or indirectly with metals and metalloids including As.

(iv) Depending on environmental parameters and hydrological conditions (i.e. level of AMD input), distinct microbial communities are likely to contribute to As biogeochemical cycling in streambed sediments through Fe, Mn, As reduction, As oxydation or As biomethylation.

To improve our understanding of arsenic biogeochemical cycling in AMD-affected streams, further investigations are necessary including: (i) the characterisation of sorption equilibria of As species at the surface of Al-ferrihydrites and their fate during reductive dissolution; (ii) the investigation of methylation processes, and potentially volatilisation; (iii) the deeper analysis of the microbial diversity including Bacteria, Archaea 
and Eukaryotes by a high-throughput sequencing, the microorganisms playing a key role in an ecosystem not being necessarily the more abundant; (iv) the targeting of key microbial functions such as arsenic methylation and $\mathrm{As}^{\mathrm{V}}$ reduction; (v) the isolation of bacteria from the sediment (e.g. Rhodobacter spp.) and the study of their potential capacities to interact with the As cycle and (v) the scaling up of the experimental design for a better representativeness (in situ experiments).

\section{Acknowledgements}

This study was supported by University of Montpellier 2 allocation and EC2CO program (Ecodyn, Biohefect). The authors thank Mickael Cros for technical help. Part of the field chemical data was acquired through the OSU OREME.

\section{References}

[1] D. B. Johnson, K. B. Hallberg, Acid mine drainage remediation options: a review. Sci. Total Environ. 2005, 338, 3. doi:10.1016/ J.SCITOTENV.2004.09.002

[2] B. A. Butler, Effect of $\mathrm{pH}$, ionic strength, dissolved organic carbon, time, and particle size on metals release from mine drainage impacted streambed sediments. Water Res. 2009, 43, 1392. doi:10.1016/ J.WATRES.2008.12.009

[3] B. A. Butler, Effect of imposed anaerobic conditions on metals release from acid-mine drainage contaminated streambed sediments. Water Res. 2011, 45, 328. doi:10.1016/J.WATRES.2010.07.077

[4] J. M. Park, J. S. Lee, J. U. Lee, H. T. Chon, M. C. Jung, Microbial effects on geochemical behavior of arsenic in As-contaminated sediments. J. Geochem. Explor. 2006, 88, 134. doi:10.1016/J.GEX PLO.2005.08.026

[5] K. H. Nealson, Sediment bacteria: who's there, what are they doing, and what's new? Annu. Rev. Earth Planet. Sci. 1997, 25, 403. doi:10.1146/ANNUREV.EARTH.25.1.403

[6] C. Lors, C. Tiffreau, A. Laboudigue, Effects of bacterial activities on the release of heavy metals from contaminated dredged sediments. Chemosphere 2004, 56, 619. doi:10.1016/J.CHEMOSPHERE.2004. 04.009

[7] P. L. Smedley, D. G. Kinniburgh, A review of the source, behaviour and distribution of arsenic in natural waters. Appl. Geochem. 2002, 17, 517. doi:10.1016/S0883-2927(02)00018-5

[8] B. K. Mandal, K. T. Suzuki, Arsenic round the world: a review. Talanta 2002, 58, 201. doi:10.1016/S0039-9140(02)00268-0

[9] C. Casiot, S. Lebrun, G. Morin, O. Bruneel, J. C. Personné, F. ElbazPoulichet, Sorption and redox processes controlling arsenic fate and transport in a stream impacted by acid mine drainage. Sci. Total Environ. 2005, 347, 122. doi:10.1016/J.SCITOTENV.2004.12.039

[10] H. Cheng, Y. Hub, J. Luoc, B. Xua, J. Zhao, Geochemical processes controlling fate and transport of arsenic in acid mine drainage (AMD) and natural systems. J. Hazard. Mater. 2009, 165, 13. doi:10.1016/ J.JHAZMAT.2008.10.070

[11] T. Z. Guo, R. D. DeLaune, W. H. Patrick, The influence of sediment redox chemistry on chemically active forms of arsenic, cadmium, chromium, and zinc in estuarine sediment. Environ. Int. 1997, 23, 305. doi:10.1016/S0160-4120(97)00033-0

[12] H. W. Langner, W. P. Inskeep, Microbial reduction of arsenate in the presence of ferrihydrite. Environ. Sci. Technol. 2000, 34, 3131. doi:10.1021/ES991414Z

[13] Y. Takahashi, R. Minamikawa, K. H. Hattori, K. Kurishima, N. Kihou, K. Yuita, Arsenic behavior in paddy fields during the cycle of flooded and non-flooded periods. Environ. Sci. Technol. 2004, 38, 1038. doi:10.1021/ES034383N

[14] M. Herbel, S. Fendorf, Biogeochemical processes controlling the speciation and transport of arsenic within iron coated sands. Chem. Geol. 2006, 228, 16. doi:10.1016/J.CHEMGEO.2005.11.016

[15] J. Routh, A. Bhattacharya, A. Saraswathy, G. Jacks, P. Bhattacharya, Arsenic remobilization from sediments contaminated with mine tailings near the Adak mine in Vasterbotten district (northern
Sweden). J. Geochem. Explor. 2007, 92, 43. doi:10.1016/ J.GEXPLO.2006.07.003

[16] D. A. Rubinos, L. Iglesias, F. Diaz-Fierros, M. T. Barral, Interacting effect of $\mathrm{pH}$, phosphate and time on the release of arsenic from polluted river sediments (Anllóns River, Spain). Aquat. Geochem. 2011, 17, 281. doi:10.1007/S10498-011-9135-2

[17] S. Dixit, J. G. Hering, Comparison of $\operatorname{arsenic}(\mathrm{V})$ and $\operatorname{arsenic}(\mathrm{III})$ sorption onto iron oxide minerals: implications for arsenic mobility. Environ. Sci. Technol. 2003, 37, 4182. doi:10.1021/ES030309T

[18] K. J. Tufano, C. Reyes, C. W. Saltikov, S. Fendorf, Reductive processes controlling arsenic retention: revealing the relative importance of iron and arsenic reduction. Environ. Sci. Technol. 2008, 42, 8283. doi:10.1021/ES801059S

[19] S. Silver, K. Budd, K. M. Leahy, W. V. Shaw, D. Hammond, R. P. Novick, G. R. Willsky, M. H. Malamy, H. Rosenberg, Inducible plasmid determined resistance to arsenate, arsenite, and antimony(III) in Escherichia coli and Staphylococcus aureus. J. Bacteriol. 1981, 146, 983.

[20] R. S. Oremland, J. F. Stolz, The ecology of arsenic. Science 2003, 300, 939. doi:10.1126/SCIENCE.1081903

[21] M. Azizur Rahman, H. Hasegawa, Arsenic in freshwater systems: Influence of eutrophication on occurrence, distribution, speciation, and bioaccumulation. Appl. Geochem. 2012, 27, 304. doi:10.1016/ J.APGEOCHEM.2011.09.020

[22] X. X. Yin, J. Chen, J. Qin, G.-X. Sun, B. P. Rosen, Y.-G. Zhu, Biotransformation and volatilization of arsenic by three photosynthetic cyanobacteria. Plant Physiol. 2011, 156, 1631. doi:10.1104/PP.111.178947

[23] C. Casiot, M. Egal, O. Bruneel, C. Bancon-Montigny, M. A. Cordier, E. Gomez, C. Aliaume, F. Elbaz-Poulichet, Hydrological and geochemical controls on metals and arsenic in a Mediterranean river contaminated by acid mine drainage (the Amous river, France); preliminary assessment of impacts on fish (Leuciscus cephalus). Appl. Geochem. 2009, 24, 787. doi:10.1016/J.APGEOCHEM.2009.01.006

[24] M. Leblanc, B. Achard, D. Ben Othman, J. M. Luck, Accumulation of arsenic from acidic mine waters by ferruginous bacterial accretions (stromatolites). Appl. Geochem. 1996, 11, 541. doi:10.1016/08832927(96)00010-8

[25] C. Casiot, G. Morin, F. Juillot, O. Bruneel, J. C. Personné, M. Leblanc, K. Duquesne, V. Bonnefoy, F. Elbaz-Poulichet, Bacterial immobilization and oxidation of arsenic in acid mine drainage (Carnoulès Creek, France). Water Res. 2003, 37, 2929. doi:10.1016/S0043-1354 (03)00080-0

[26] W. G. Weisburg, S. M. Barns, D. A. Pelletier, D. J. Lane, 16S Ribosomal DNA amplification for phylogenetic study. J. Bacteriol. 1991, 173, 697.

[27] S. F. Altschul, W. Gish, W. Miller, E. W. Myers, D. J. Lipman, Basic local alignment search tool. J. Mol. Biol. 1990, 215, 403. doi:10.1016/ S0022-2836(05)80360-2

[28] R. C. Edgar, B. J. Haas, J. C. Clemente, C. Quince, R. Knight, UCHIME improves sensitivity and speed of chimera detection. Bioinformatics 2011, 27, 2194. doi:10.1093/BIOINFORMATICS/ BTR381

[29] P. D. Schloss, S. L. Westcott, T. Ryabin, J. R. Hall, M. Hartmann, E. B. Hollister, R. A. Lesniewski, B. B. Oakley, D. H. Parks, C. J. Robinson, J. W. Sahl, B. Stres, G. G. Thallinger, D. J. Van Horn, C. F. Weber, Introducing mothur: open-source, platform-independent, communitysupported software for describing and comparing microbial communities. Appl. Environ. Microbiol. 2009, 75, 7537. doi:10.1128/ AEM.01541-09

[30] M. Cardinale, L. Brusetti, P. Quatrini, S. Borin, A. M. Puglia, A. Rizzi, A. Zanardini, C. Sorlini, C. Corselli, D. Daffonchio, Comparison of different primer sets for use in automated ribosomal intergenic spacer analysis of complex bacterial communities. Appl. Environ. Microbiol. 2004, 70, 6147. doi:10.1128/AEM.70.10.6147-6156.2004

[31] D. K. Nordstrom, Hydrogeochemical processes governing the origin, transport and fate of major and trace elements from mine wastes and mineralized rock to surface waters. Appl. Geochem. 2011, 26, 1777. doi:10.1016/J.APGEOCHEM.2011.06.002 
[32] A. Adra, G. Morin, G. Ona-Nguema, N. Menguy, F. Maillot, C. Casiot, O. Bruneel, S. Lebrun, F. Juillot, J. Brest, Arsenic scavenging by aluminum-substituted ferrihydrites in a circumneutral $\mathrm{pH}$ river impacted by acid mine drainage. Environ. Sci. Technol. 2013, 47, 12 784. doi:10.1021/ES4020234

[33] G. L. Rupp, V. D. Adams, Calcium Carbonate Precipitation as Influenced by Stream Primary Production. Paper 1161981 (Utah State University, Utah Water Research Laboratory: Logan, UT). Available at http://digitalcommons.usu.edu/water_rep/116 [Verified 20 June 2014].

[34] G. Lee, J. M. Bigham, G. Faure, Removal of trace metals by coprecipitation with $\mathrm{Fe}, \mathrm{Al}$ and $\mathrm{Mn}$ from natural waters contaminated with acid mine drainage in the Ducktown Mining District, Tennessee. Appl. Geochem. 2002, 17, 569. doi:10.1016/S0883-2927(01)00125-1

[35] K. Koffi, M. Leblanc, H. Jourde, C. Casiot, S. Pistre, P. Gouze, F. Elbaz-Poulichet, Reverse oxidation zoning at a mine tailings stock generating arsenic-rich acid waters (Carnoulès, France). Mine Water Environ. 2003, 22, 7. doi:10.1007/S102300300002

[36] M. P. Asta, C. Ayora, G. Román-Ross, J. Cama, P. Acero, A. G. Gault, J. M. Charnock, F. Bardelli, Natural attenuation of arsenic in the Tinto Santa Rosa acid stream (Iberian Pyritic Belt, SW Spain): the role of iron precipitates. Chem. Geol. 2010, 271, 1. doi:10.1016/ J.CHEMGEO.2009.12.005

[37] J. Majzlan, B. Lalinská, M. Chovan, L. Jurkovič, S. Milovská, J. Göttlicher, The formation, structure, and ageing of As-rich hydrous ferric oxide at the abandoned $\mathrm{Sb}$ deposit Pezinok (Slovakia) Geochim. Cosmochim. Acta 2007, 71, 4206. doi:10.1016/J.GCA. 2007.06.053

[38] P. Byrne, P. J. Wood, I. Reid, The impairment of river systems by metal mine contamination: a review including remediation options. Crit. Rev. Environ. Sci. Technol. 2012, 42, 2017. doi:10.1080/ 10643389.2011.574103

[39] L. Giotta, A. Agostiano, F. Italiano, F. Milano, M. Trotta, Heavy metal ion influence on the photosynthetic growth of Rhodobacter sphaeroides. Chemosphere 2006, 62, 1490. doi:10.1016/J.CHEMO SPHERE.2005.06.014

[40] B. B. Nepple, J. Kessi, R. Bachofen, Chromate reduction by Rhodobacter sphaeroides. J. Ind. Microbiol. Biotechnol. 2000, 25, 198. doi:10.1038/SJ.JIM.7000049

[41] J. M. Yagi, D. Sims, T. Brettin, D. Bruce, E. L. Madsen, The genome of Polaromonas naphthalenivorans strain CJ2, isolated from coal tarcontaminated sediment, reveals physiological and metabolic versatility and evolution through extensive horizontal gene transfer. Environ. Microbiol. 2009, 11, 2253. doi:10.1111/J.1462-2920.2009.01947.X

[42] L. Haller, M. Tonoll, J. Zopfi, R. Peduzzi, W. Wildi, J. Poté, Composition of bacterial and archaeal communities in freshwater sediments with different contamination levels (Lake Geneva, Switzerland). Water Res. 2011, 45, 1213. doi:10.1016/J.WATRES.2010.11.018

[43] T. R. Miller, A. L. Delcher, S. L. Salzberg, E. Saunders, J. C. Detter, R. U. Halden, Genome sequence of the dioxin-mineralizing bacterium Sphingomonas wittichii RW1. J. Bacteriol. 2010, 192, 6101. doi:10.1128/JB.01030-10

[44] V. A. Jackson, A. N. Paulse, J. P. Odendaal, S. Khan, W. Khan, Identification of metal tolerant organisms isolated from the Plankenburg River, Western Cape, South Africa. Water S.A. 2012, 38, 29. doi:10.4314/WSA.V38I1.5

[45] M. E. Farias, S. Revale, E. Mancini, O. Ordonez, A. Turjanski, N. Cortez, M. P. Vazquez, Genome sequence of Sphingomonas sp. $\mathrm{S} 17$, isolated from an alkaline, hyperarsenic, and hypersaline volcanoassociated lake at high altitude in the Argentinean puna. J. Bacteriol. 2011, 193, 3686. doi:10.1128/JB.05225-11

[46] G. Lear, B. Song, A. G. Gault, D. A. Polya, J. R. Lloyd, Molecular analysis of arsenate-reducing bacteria within Cambodian sediments following amendment with acetate. Appl. Environ. Microbiol. 2007, 73, 1041. doi:10.1128/AEM.01654-06

[47] D. C. White, S. D. Suttont, D. B. Ringelberg, The genus Sphingomonas: physiology and ecology. Curr. Opin. Biotechnol. 1996, 7, 301. doi:10.1016/S0958-1669(96)80034-6

[48] Z. J. Zhou, H. Q. Yin, Y. Liu, M. Xie, G. Z. Qiu, X. D. Liu, Diversity of microbial community at acid mine drainages from Dachang metals-rich mine, China. Trans. Nonferrous Met. Soc. China 2010, 20, 1097. doi:10.1016/S1003-6326(09)60263-6

[49] D. R. Nicholas, S. Ramamoorthy, V. Palace, S. Spring, J. N. Moore, R. F. Rosenzweig, Biogeochemical transformations of arsenic in circumneutral freshwater sediments. Biodegradation 2003, 14, 123. doi:10.1023/A:1024031700533

[50] W. M. Mok, C. M. Wai, Distribution and mobilization of arsenic and antimony species in the Coeur d'Alene river, Idaho. Environ. Sci. Technol. 1990, 24, 102. doi:10.1021/ES00071A012

[51] F. S. Islam, A. G. Gault, C. Boothman, D. A. Polya, J. M. Charnock, D. Chatterjee, J. R. Lloyd, Role of metal-reducing bacteria in arsenic release from Bengal delta sediments. Nature 2004, 430, 68. doi:10.1038/NATURE02638

[52] H. A. L. Rowland, R. L. Pederick, D. A. Polya, R. D. Pancost, B. E. Van Dongen, A. G. Gault, D. J. Vaughan, C. Bryant, B. Anderson, J. R. Lloyd, The control of organic matter on microbially mediated iron reduction and arsenic release in shallow alluvial aquifers, Cambodia. Geobiology 2007, 5, 281. doi:10.1111/J.1472-4669.2007.00100.X

[53] M. Héry, B. E. van Dongen, F. Gill, D. Mondal, D. J. Vaughan, R. D. Pancost, D. A. Polya, J. R. Lloyd, Arsenic release and attenuation in low organic carbon aquifer sediments from West Bengal. Geobiology 2010, 8, 155. doi:10.1111/J.1472-4669.2010.00233.X

[54] L. Giloteaux, D. E. Holmes, K. H. Williams, K. C. Wrighton, M. J. Wilkins, A. P. Montgomery, J. A. Smith, R. Orellana, C. A. Thompson, T. J. Roper, P. E. Long, D. R. Lovley, Characterization and transcription of arsenic respiration and resistance genes during in situ uranium bioremediation. ISME J. 2013, 7, 370. doi:10.1038/ISMEJ.2012.109

[55] Y. Masue-Slowey, R. H. Loeppert, S. Fendorf, Alteration of ferrihydrite reductive dissolution and transformation by adsorbed As and structural Al: implications for As retention. Geochim. Cosmochim. Acta 2011, 75, 870. doi:10.1016/J.GCA.2010.11.016

[56] J. R. Lloyd, A. G. Gault, M. Héry, J. D. MacRae, Microbial transformations of arsenic in the subsurface. In Environmental Microbe-Metal Interactions II (Eds J. F. Stolz, R. S, Oremland), 2011, pp. 77-90 (ASM Press: Washington, DC).

[57] S. C. Ying, Y. Masue-Slowey, B. D. Kocar, S. D. Griffis, S. Webb, M. A. Marcus, C. A. Francis, S. Fendorf, Distributed microbially and chemically mediated redox processes controlling arsenic dynamics within $\mathrm{Mn}$-/Fe-oxide constructed aggregates. Geochim. Cosmochim. Acta 2013, 104, 29. doi:10.1016/J.GCA.2012.08.020

[58] K. Bosecker, Bioleaching: metal solubilization by microorganisms. FEMS Microbiol. Rev. 1997, 20, 591. doi:10.1111/J.1574-6976.1997. TB00340.X

[59] R. N. vanden Hoven, J. M. Santini, Arsenite oxidation by the heterotroph Hydrogenophaga sp. str. NT-14: the arsenite oxidase and its physiological electron acceptor. Biochim. Biophys. Acta 2004, 1656, 148. doi:10.1016/J.BBABIO.2004.03.001

[60] R. Bentley, T. G. Chasteen, Microbial methylation of metalloids: arsenic, antimony, and bismuth. Microbiol. Mol. Biol. Rev. 2002, 66, 250. doi:10.1128/MMBR.66.2.250-271.2002

[61] J. Meyer, K. Michalke, T. Kouril, R. Hensel, Volatilisation of metals and metalloids: an inherent feature of methanoarchaea? Syst. Appl. Microbiol. 2008, 31, 81. doi:10.1016/J.SYAPM.2008.02.001

[62] J. Ye, C. Rensing, B. P. Rosen, Y.-G. Zhu, Arsenic biomethylation by photosynthetic organisms. Trends Plant Sci. 2012, 17, 155. doi:10.1016/J.TPLANTS.2011.12.003

[63] A. Mestrot, J. Feldmann, E. M. Krupp, M. S. Hossain, G. Roman-Ross, A. A. Meharg, Field fluxes and speciation of arsines emanating from soils. Environ. Sci. Technol. 2011, 45, 1798. doi:10.1021/ES103463D

[64] Y. Jia, H. Huang, M. Zhong, F.-H. Wang, L.-M. Zhang, Y.-G. Zhu, Microbial arsenic methylation in soil and rice rhizosphere. Environ. Sci. Technol. 2013, 47, 3141.

[65] S. A. Nagorski, J. N. Moore, Arsenic mobilization in the hyporheic zone of a contaminated stream. Water Resour. Res. 1999, 35, 3441. doi:10.1029/1999WR900204

[66] L. Duester, J. P. M. Vink, A. V. Hirner, Methylantimony and-arsenic Species in sediment pore water tested with the sediment or fauna incubation experiment. Environ. Sci. Technol. 2008, 42, 5866. doi:10.1021/ES800272H 